\title{
INTERJECTIONS IN LITERARY READINGS AND ARTISTIC PERFORMANCE
}

\author{
Daniel C. O’Connell, Sabine Kowal and Scott P. King
}

\begin{abstract}
Numerosity and privileges of occurrence of various types of interjections (primary conventional, primary non-conventional, secondary, and onomatopoeic) were investigated in three different literary readings of Winnie-the-Pooh (Milne 1926), in one reading of Ulysses (Joyce 1960), and in an artistic performance by actors (the film The third man, Korda, Selznik, \& Reed 1949). The spoken corpora, based on printed texts as source, consisted of 667 interjections. Ameka's (1992 b, 1994) hypothesis that, parallel to their independence from ambient grammar, interjections would also be isolated temporally by preceding and following pauses, was not confirmed; for the entire corpus, only $39 \%$ of all interjections were thus isolated. However, an alternative hypothesis, that interjections serve an initializing function, was confirmed: Altogether, 77\% of the interjections were found to be initializing, i.e., were preceded by a pause, introduced a speaking turn, introduced an utterance, and/or introduced a citation. Primary conventional interjections constituted the majority of interjections (overall 56\%), but only two of these were common to all the corpora $(o h$ and $a h)$. By far the highest percentage $(28 \%)$ of primary nonconventional interjections occurred in the artistic performance of The third man. None of these occurred in either the novel or the screenplay of The third man, unlike the primary non-conventional interjections throughout the text of the literary readings. Functions of interjections are discussed in terms of Goffman's (1981: 226) animators (literary readers, 26\% of whose spoken interjections were added to those in the printed text) and principals (actors, $79 \%$ of whose spoken interjections were added to those in the printed text), in terms of literacy and orality, and in terms of the emotional stance and perspective of a speaker at the very moment of utterance.
\end{abstract}

Keywords: Interjection; Literary reading; Artistic performance in film; Literacy/orality.

\section{Introduction}

A recent film, March of the Penguins (Jacquet 2005), gradually lures the audience into experiencing the birds as almost human. Quite in accord with this impression, when a chubby penguin is seen to slip on the ice and fall flat on her back, the audience perceives her as emitting a genuine $u g h$. This reaction would have warmed the heart of Wilhelm Wundt (1900), who theorized that the origin of human interjections lay in the use of animal cries.

Wundt's anthropomorphism regarding the use of interjections is not as naïve, outmoded, and off the mark as one might imagine, and it is surely far from being the nadir of theoretical thinking about a linguistic phenomenon that, according to Harris (1980: 20), has been considered one of "the ragbag categories" for European grammarians. Interjections have been "an unpopular subject in linguistics" (Ehlich 1986: 1; our translation) and, despite the pragmatic turn of linguistics in the 1970s, have 
had only a "shadowy existence in the grammars of the twentieth century" (Burkhardt 1998: 492; our translation). According to Hansen (1998: 41), the neglect of interjections in modern linguistics can be related to its written language bias as well as to its focus on the referential function of language, a focus which is in itself not inclusive of the emotional aspects of language use and therefore not inclusive of interjections. Nonetheless, what little research has been undertaken has proceeded largely from a linguistic perspective, as Ameka's (1992 b) review of the literature indicates. For example, Fries $(1988,1990,1992)$ has provided detailed analyses of grammatical aspects of interjections, and a special issue of the Journal of Pragmatics (Ameka 1992 a) was devoted to semantic and pragmatic aspects of interjections in various European and non-European languages. More recently, Nübling (2004: 11; our translation) has proposed a taxonomy in an attempt to define "the prototypical interjection" linguistically on the basis of various "parameters of interjectionality" (16; our translation). In this taxonomy, "emotionality and expressiveness" (17; our translation) are considered the basic functional criteria in determining "ideal types of interjections" (17; our translation) and distinguishing them from other particles on an "interjectional spectrum" (11).

A more general emphasis on the psychological state of the speaker at the very moment of utterance as prerequisite for the use of interjections had already been formulated by Jespersen (1922: 415): "The usual interjections are abrupt expressions for sudden sensations and emotions." Ameka (1992 b) has taken up Jespersen's idea in his own classification of interjections according to their expressive, conative, and phatic functions. And in a similar vein, some researchers have emphasized the involvement of the whole human body in expressive spontaneous speech and have accordingly related interjections to gestures (e.g., Karcevski 1941: 62 f.; Eastman 1992; Müller \& Posner 2004): A person who is confronted with a sudden change in his or her momentary situation can be expected to react to it spontaneously with interjections, gestures, and other nonverbal expressions; and sometimes gestures may be used instead of interjections (Ameka 1994: 1712).

All the above mentioned functional classifications of interjections have to do with spoken discourse. But, as is well known to readers of novels and plays, interjections also occur in written discourse as a simulation of spontaneous spoken dialogue. To date, however, their form and function in literature have hardly been investigated (but see, e.g., several German-language studies: Schneider 1959; Burger 1980; Kleemann 1980). Thus, little is known by way of systematic research as to how interjections find their way into print (frequently with unorthodox orthography), and to what extent written dialogue that simulates spontaneous spoken dialogue is in keeping with the actual use of interjections in authentic spontaneous spoken dialogue.

Still, no one has as yet succeeded in authoritatively defining interjections on formal and/or functional grounds and thus properly segregating their domain. For example, in English, they are thought to be independent of the ambient grammatical structure; but this does not seem to be the case in all languages (see Yang 2004). Nor are they notably in accord with the phonetic-phonological constraints of the language (see Pompino-Marschall 2004).

Historically, Wundt (1900: $319 \mathrm{ff}$.) traced the ontogeny of interjections from the natural cries of preverbal infants to standardized interjections which he categorized into primary and secondary. Thus the child's shriek eventually yields to a conventional ouch. According to Wundt, such primary interjections remain close to natural cries and 
have little relationship to a language except to use the sounds thereof. Secondary interjections, however, use lexical items from the language or add a lexical item to a primary interjection (e.g., God or oh God). Only much later (Rhodes 1992: 222) were primary interjections divided into conventional or "tame" (e.g., oh) and nonconventional or "'wild' interjections violating the syllable canon, e.g., Pst 'attention', or made of phones not found in other words, e.g., Yech/Yuck." In our own analyses of interjections, we have operationally defined primary conventional interjections as those which appear in Merriam-Webster's collegiate dictionary (2003); all other primary interjections have been considered non-conventional or wild. To these categories we have added secondary and onomatopoeic interjections, which themselves mimic sounds (e.g., swish, bang, miaow).

Empirical issues regarding the use of interjections in spontaneous spoken dialogue are further discussed in several of our own recent psycholinguistic investigations (Kowal \& O'Connell 2004; O'Connell \& Kowal 2005 b; O'Connell, Kowal, \& Ageneau 2005; O'Connell, Kowal, \& Dill 2004). An initial methodological problem was to find corpora that were of media acoustic quality and at the same time provided a sufficiency of interjections for reliable analysis; excellent acoustic quality is peculiarly necessary insofar as interjections frequently violate the phonology of a given language and may be uttered rapidly and softly. We found political interviews, up until then our preferred speech genre for investigation, to be singularly deficient in the latter of these two prerequisites; such interviews are typically so carefully controlled and diplomatically formulated as to be lacking in the spontaneity and emotional expression that elicit interjections. Hence, our first empirical study of interjections was instead a personal interview of Günter Gaus on German television with Katarina Witt, an Olympic ice-skating champion (Kowal \& O'Connell 2004). Moving then from German to English, we compared the paucity of interjections in political media interviews of Hillary Clinton with the abundance of interjections in a media interview of the comedian Robin Williams (O'Connell et al. 2005). And because the signature "Ah-ahah-ow-ow-ow-oo," a primary non-conventional interjection, of Eliza Doolittle in Shaw's (1916/1969: 11) Pygmalion is central to the theme of the play, we (O'Connell \& Kowal 2005 b) analyzed the use of interjections in the feature film Pygmalion (Pascal, Asquith, \& Howard 1938).

One of the empirical issues in our research has been the rejection of Ameka's (1992 b, 1994) hypothesis that the grammatical isolation of English interjections is paralleled by their temporal isolation in spoken discourse, i.e., by pauses preceding and following them. Accordingly, O'Connell et al. (2005: 161, Table IV) have presented data from three sets of media interviews for interjections in either embedded, isolated, initial, or final positions relative to ambient pauses. Contrary to Ameka's hypothesis, all three data sets yielded low percentages of interjections isolated by pauses $(20 \%, 12 \%$, and $19 \%$, respectively). Instead, interjections were found to be typically embedded in ongoing speech without any pause $(43 \%, 54 \%$, and $45 \%$, respectively). However, a quite different hypothesis was confirmed by these same data (O'Connell et al. 2005: 164). This hypothesis too concerned the position of interjections, but postulated that interjections are typically used by speakers at the beginning of one or the other of the following units which are themselves characteristic of spontaneous spoken dialogue: speaker turns, cited speech within a speaker turn, and articulatory phrases within speaker turns (i.e., after an initial pause; articulatory phrases are defined as an utterance not interrupted by a pause). Since these categories (i.e., a speaker turn, cited speech 
within a speaker turn, and an articulatory phrase within a speaker turn) can co-occur simultaneously at the same position, care must be taken not to inflate occurrence through double counting. The percentages that reflect this initializing function of interjections are, for the same sets of data as are reported above, $80 \%, 71 \%$, and $74 \%$, respectively. This finding confirms Nübling's (2004: 31) observations regarding the sequencing of interjections. In her analyses of informal conversations from the LondonLund corpus of spoken British English (Svartvik \& Quirk 1980), Aijmer (1987: 83) too emphasized the initializing function of interjections: When $o h$ and $a h$ were used in reported speech, they were "always introducing the reported speech."

The related question as to what particles are to be included as interjections also remains an empirical as well as a theoretical problem. For example, the discourse marker well is often included as an interjection (e.g., Rhodes 1992: 222). In turn, interjections are sometimes listed as discourse markers (e.g., oh in Jucker \& Smith 1998). The inclusion of onomatopoeia in the word class interjection has also been controversial. According to Tesnière (1936: 347), there are three functional types of interjections to be distinguished: Imperative interjections express the intention of the speaker to influence the consciousness of the listener; impulsive interjections are a bodily, emotional, or cognitive reaction of the speaker to some event in her or his immediate environment; and imitative (i.e., onomatopoeic) interjections mimic sounds (see also Burkhardt 1998 and Wilkins 1992, both of whom include onomatopoeic interjections). By contrast, Ameka (1994: 1712) argues that, from a semantic point of view, instances of onomatopoeia would have to be excluded because they "are descriptive rather than expressive." Reisigl (1999: 199 ff.) also excludes them, but on the basis of their intonation and syntax. Nübling (2004: 37) excludes onomatopoeia from the word class interjection on the basis of functional criteria while including it on the basis of formal criteria. In view of the lack of consensus and the paucity of empirical data we have included onomatopoeic interjections in the present research.

The problem of inclusion as interjections also extends to fillers. Clark and Fox Tree (2002: 104) contend that the fillers " $u h$ and $u m$ are interjections," to which O'Connell and Kowal (2004: 471) have replied:

As interjections, these two fillers would have to be granted a very special status by reason of their peculiar properties of duration, position, and function, quite unlike not only stereotypic primary interjections, but also unlike any other interjections.

In fact, Kowal and O'Connell (2004) found that the German filler $\ddot{a} h$ was distributed differentially from primary, secondary, and onomatopoeic interjections: $\ddot{A} h$ was typically $(52 \%)$ used in final position with respect to ambient pauses, i.e., at the end of an articulatory phrase, whereas only $7 \%$ of all interjections occurred in this position; $\ddot{a} h$ was seldom used $(4 \%)$ at the beginning of speaker turns, whereas $41 \%$ of all interjections were used in this position; and $\ddot{a} h$ was used only once (2\%) at the beginning of quoted speech, whereas $30 \%$ of all interjections occurred in this position. O'Connell and Kowal's (2005 a) data confirmed the differential distribution of fillers and interjections for $u h$ and $u m$ : Fillers did occur reasonably often in initial position with respect to ambient pauses (45\%), but they never introduced cited speech, and they never constituted an integral turn. 
Finally, the inclusion of yes/no and ja/nein as interjections is also controversial. Ameka (1994: 1712) contends that yes and no are English interjections. Tesnière (1936: 350) considered phonologically aberrant forms of affirmation and negation, e.g., nee in German, to be interjections. Wikipedia (http://de.wikipedia.org/wiki) insists that ja and nein are German interjections (but see Angermeyer 1979; Burkhardt 1998). Kowal and O'Connell (2004) have found modest evidence that aberrant forms of the German nein are functionally different from interjections. In lieu of further empirical evidence, we have chosen to exclude yes/no from the present study.

The brief review of the literature given above indicates that listings and discussions of interjections remain notoriously variable. In terms of genres, at the two extremes - well-formed expository prose and vigorous spontaneous spoken dialogue the incidence of interjections is predictably minimized and maximized, respectively. In accord with Koch and Oesterreicher (1994), the occurrence of interjections follows both medial and conceptual orality rather than medial and conceptual literacy.

Because of both its complexity and its importance in our psycholinguistic analyses of interjections, the nomenclature of Koch and Oesterreicher requires further explication. Medial literacy and orality constitute dichotomous variables: One or the other modality, writing or speaking, characterizes a given corpus. Conceptual literacy and orality on the other hand are continuous variables that can characterize either writing or speaking. Typically, conceptual literacy is stylistically well-formed and syntactically correct, whereas conceptual orality is characterized by numerous particles, delays, hesitations, false starts, ellipsis, contractions and elisions, overlap, and interruptions. But written discourse can simulate the conceptual orality of spontaneous spoken discourse stylistically, and spontaneous spoken discourse can approximate the formal correctness of the conceptual literacy of written discourse. For example, the following utterance (O'Connell et al. 2005: 168), although spoken spontaneously by David Letterman, is conceptually literate: "I know nothing about politics; I just sit here and watch it go by," whereas the following (O'Connell \& Kowal 2005 b: 510), although it is excerpted from a written text in Shaw's (1916/1969: 81) play Pygmalion, is conceptually oral: "HIGGINS (with a crow of triumph): Aha! Just so. A-a-a-ahowooh!" In the present research, the written texts represent medial literacy, and the literary readings and artistic performance themselves represent medial orality. But, insofar as both the literary readings and the artistic performance are derived from written texts, they should be expected to exemplify a moderate mixture of conceptual literacy and conceptual orality. Hence, the use - by the literary readers and/or the actors - of interjections not in their respective written texts would constitute a notable instance of conceptual orality.

The actual functions and privileges of occurrence of interjections still remain in need of extensive empirical research. O'Connell et al.'s (2005: 169) findings pinpoint "two basic uses of interjections": "One is an expression of emotional experience, a turn that consists only of an interjection without additional words. ... The other use involves the initiating role of the interjection; cognitive content follows thereupon." And as O'Connell and Kowal (2005 b: 513) have added, the prototypical primary interjections are

emotional and spontaneous. They are also short, not declinable [i.e., not morphologically alterable], not morphologically derivable, and without lexical 
meaning. They are usable alone as integral utterances, turns, or sentence substitutes.

Fillers are typically low on emotionality and cannot be used alone as integral utterances, turns, or sentence substitutes and should therefore not be thought of as interjections.

To date, our research on interjections has been concerned mostly with spontaneous spoken dialogue in media interviews. Our Pygmalion research (O'Connell \& Kowal $2005 \mathrm{~b}$ ) has provided a transition to spoken corpora based on a printed source. In the following research, we engage spoken discourse based differentially on printed text, i.e., with variation in the amount of dependence on the text itself: literary readings and artistic performance. The former are more closely related to the printed text in that they are essentially read aloud by a professional reader, whereas the actors in an artistic performance rely on the memorization of their lines from the screenplay. In this respect, readers and actors may plausibly instantiate different speech genres. It can be expected that the artistic performance of actors involves far more than simply accessing memorized lines; they must engage the role with their entire body - movement, stance, and gesture, in addition to verbalization of the lines.

Goffman (1981: 226) has provided a nomenclature that distinguishes conveniently various meanings of the term speaker:

One meaning, perhaps the dominant, is that of animator, that is, the sounding box from which utterances come. A second is author, the agent who puts together, composes, or scripts the lines that are uttered. A third is that of principal, the party to whose position, stand, and belief the words attest.

In accord with Goffman's categories, we would characterize a literary reader as an "animator" and an actor as a "principal". And insofar as the literary readers and actors add interjections that were not in the printed text, they also enter into the role of "author."

And so, over and above the need to confirm our recent findings regarding the functions of interjections, the present research engages particularly a hypothesized differentiation of literary readings and artistic performance: that a greater number of interjections would be added by the actors in The third man than by the literary readers. Such a finding would distinguish the artistic performance from the literary readings as significantly more conceptually oral.

\section{Corpora}

In order to further examine these hypotheses, three corpora of interjections have been selected for the present research. The first of these, readings from A. A. Milne's (1926) Winnie the-Pooh, is divided into three sub-corpora of readings: Chapters 1, 6, and 9 as read by Charles Kuralt (1998) and by Judith Dench (Milne, Fry, Dench, Horrocks, Palmer, \& Williams 1998) and Chapters 1 and 6 as read by Bennett, Briers, and Kendal (1988). The second corpus consists of readings of selections from James Joyce's (1960) Ulysses by a pair of British actors (Norton \& Riordan 1994). The third corpus consists of an artistic performance of the film The third man (Korda, Selznik, \& Reed 1949), based remotely on the novel The third man (Greene 1950), and more proximately on the 
screenplay The third man (Greene 1984). A <geocities.com> transcript and our own transcript of the spoken performance of the feature film (involving about two dozen actors) reflect the audio component of The third man.

The three corpora have some characteristics in common: They are all derived from artistic textual sources and are performed by professional artists; all the texts are British English and the speakers are mostly British. However, the three audio subcorpora of Winnie-the-Pooh as well as the audio corpus of Ulysses are literary readings, whereas the audio corpus of the feature film The third man is an artistic performance. In addition, the Winnie-the-Pooh readings consist of children's stories and hence involve diction and syntax of less complexity than the other texts.

\section{Method}

As a working definition of interjection, we have adopted that of Wilkins (1992, as cited in Clark \& Fox Tree 2002: 76): "An interjection is (1) a conventional lexical form (sometimes a phrase) that (2) conventionally constitutes an utterance on its own and (3) doesn't enter into constructions with other word classes." Primary conventional and secondary interjections fit Wilkins' definition conveniently. However, primary nonconventional and onomatopoeic interjections do not. But they are important particles that must be taken into account in these data. Hence, we have included them as part of our corpus of interjections. As in our previous research (see O'Connell \& Kowal 2005 a), the fillers $u h$ and $u m$ are not included as interjections. Verbatim transcripts were prepared from the audio versions of all the corpora. In this process, agreement was required between the first two authors. Cases of insoluble doubt were recorded simply as a number of syllables in parentheses, e.g. $(3 \mathrm{syl})$; altogether, less than $0.1 \%$ of the corpora consists of such syllables. Interjections were categorized as primary conventional if they appeared as interjections in Merriam-Webster's collegiate dictionary (2003), e.g., oh and ah; otherwise they were categorized as primary nonconventional or "wild" (Rhodes 1992: 222), e.g., $\mathrm{mm}$ and diddlediddle. For the few German interjections that occurred in The third man, Langenscheidts Enzyklopädisches Wörterbuch der englischen und deutschen Sprache (1996) was consulted (see Table 3). Secondary interjections were identified as those involving either an additional or sole lexical item, e.g., (oh) God and for Pete's sake. Onomatopoeic interjections were identified as imitative of sounds, e.g., bang and miaow. All interjections in the Winniethe-Pooh and The third man corpora and the selections from the first 479 pages of the Ulysses corpus were subjected to acoustic analyses by means of the PRAAT software (www.praat.org). The durations of pauses preceding and following interjections were determined with a cut-off point of $0.12 \mathrm{~s}$. Thus, interjections were categorized into four types with respect to ambient pauses: Interjections neither preceded nor followed by a pause were categorized as embedded; interjections preceded, but not followed by a pause were categorized as initial; interjections followed, but not preceded by a pause were categorized as final; and interjections both preceded and followed by a pause were categorized as isolated.

Our hypotheses follow the suggestions in recent research and the genres of performance noted above. (1) A number of our own studies have provided evidence against the Ameka (1992 b; 1994) hypothesis of articulatory isolation of interjections, i.e., that they typically occur between a preceding and a following pause (parallel to 
their grammatical isolation). To the contrary, we hypothesized that interjections would largely serve an initializing function and would hence be characterized by preceding pauses (including, therefore, both the initial and isolated types). (2) We further hypothesized that overlap in the occurrence of specific interjections across corpora would be limited dominantly to primary conventional interjections and that primary non-conventional interjections would seldom occur in textual versions of the corpora, precisely because their wildness is a violation of morphological well-formedness and is instead idiosyncratically characteristic of conceptual orality. (3) Above all, we hypothesized that both the literary readers and the actors would add interjections that did not occur in the original printed text, but that the actors would add significantly more than would the literary readers. This hypothesis is a direct follow-up to our (O'Connell \& Kowal 2005 b: 511) statement regarding the actors in the film version (Pascal, Asquith, \& Howard 1938) of George Bernard Shaw's (1916/1969) Pygmalion:

In Goffman's (1981, p. 226) terms, the actors assume a partial role as authors and go beyond being mere animators to become principals, dramatis personae - the parties "to whose position, stand, and belief the words attest." The emotions expressed by the actors must be personalized; and one way to accomplish this is by the selection of interjections. This selection is very intimately associated with the expression of spontaneity.

\section{Results}

The occurrences of specific interjections of the primary conventional, primary nonconventional, secondary, and onomatopoeic types read from the text (T) and added (A) in the spoken performance of all three corpora are presented in Tables 1, 2, and 3.

\section{Table 1}

Number of Interjections (I) in Milne's (1926) Winnie-the Pooh as Read from the Text (T) and Added (A) in the Spoken Readings by Charles Kuralt (Chapters 1, 6, and 9), Judith Dench (Chapters 1, 6, and 9), and Bennett et al. (Chapters 1 and 6 Only), Respectively: Primary (Conventional and Non-conventional), Secondary, and Onomatopoeic Types

\begin{tabular}{llcccccc}
\hline Types & \multicolumn{2}{c}{ I } & \multicolumn{2}{c}{ Kuralt } & \multicolumn{2}{c}{ Dench } & \multicolumn{2}{c}{ Bennett } \\
& & T & A & T & A & T & A \\
\hline Primary & & & & & & & \\
\multirow{5}{*}{ Conventional } & & & & & & & \\
& ah & 3 & - & 3 & 1 & 2 & - \\
& aha & - & - & - & 1 & - & - \\
& eh & - & - & - & 1 & - & - \\
& hallo & 3 & - & 2 & - & 3 & - \\
& hooray & 1 & - & 1 & - & 1 & - \\
& huh & - & - & - & 1 & - & 1 \\
& oh & 17 & 1 & 19 & 8 & 9 & 5 \\
& ooh & - & - & - & 2 & - & 1
\end{tabular}


$\sum$ Conventional

Non-con- eh ow

ventional hm

kuh

$\mathrm{mm}$

$\mathrm{mm}$ warden

$\mathrm{m}-\mathrm{m}$

$\mathrm{n}$

oh oh

pf

puh

uh

umty-tiddly

umty-tiddly

umty-too

umty-too

whuh

yuh

$\sum$ Non-con-

ventional

$\sum$ All Primary

Secondary

bother

dear

dear dear

dearie

oh my dear

oh no

why

$\sum$ Secondary

Onomatopoeic bang

bump

buzz

buzz buzz buzz

crack

flk (bump)

hoohoohoo-a

kek (bump)

splash
28

30

18

189

1

$\begin{array}{ll}- & 1 \\ - & 1 \\ - & 1 \\ - & 7 \\ - & 1 \\ - & - \\ - & - \\ - & 1 \\ - & 1 \\ - & 1 \\ - & - \\ - & - \\ & \\ 1 & - \\ - & - \\ - & 1 \\ - & 1\end{array}$

20

$1 \quad 16$

$\begin{array}{ll}0 & 7\end{array}$

$30 \quad 1$

$31 \quad 34$

$18 \quad 16$

$\begin{array}{ll}3 & - \\ 5 & - \\ 1 & - \\ 2 & - \\ - & - \\ - & - \\ 1 & -\end{array}$

12 0

132

8 0

$\begin{array}{llllll}1 & - & - & - & 1 & - \\ 7 & - & - & - & 1 & - \\ 3 & - & - & - & - & - \\ - & - & 1 & - & - & - \\ 1 & - & 1 & - & 1 & - \\ - & - & - & 2 & - & - \\ - & - & - & 1 & - & - \\ - & - & - & 1 & - & - \\ 1 & - & - & - & - & -\end{array}$


$\sum$ Onomatopoeic

$\sum \Sigma$
55
130

1
2

46
4

40
3 0

$29 \quad 16$

\section{Table 2}

Number of Interjections (I) in Selections from James Joyce's (1960) Ulysses as Read from the Text (T) and Added (A) in the Spoken Readings: Primary (Conventional and Non-conventional), Secondary, and Onomatopoeic Types

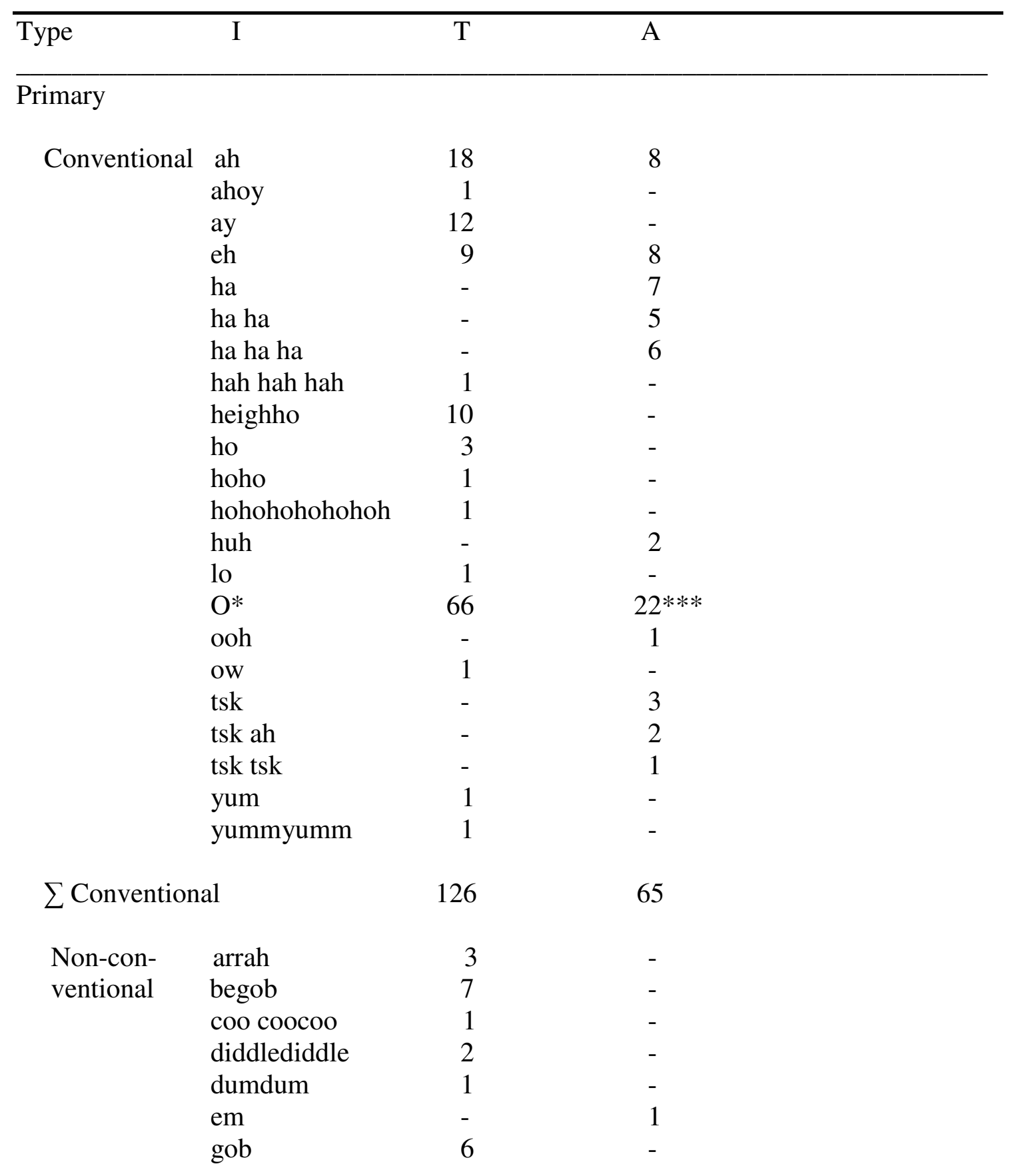




$\begin{array}{lcc}\text { heh } & - & 1 \\ \text { he he he } & 1 & - \\ \text { hm } & - & 1 \\ \text { hoopsa } & 1 & - \\ \text { lala } & 1 & - \\ \mathrm{mm} \mathrm{hm} & - & 1 \\ \mathrm{mn} & 1 & - \\ \text { tolloll } & 1 & - \\ \text { uh } & - & 6 \\ \text { womwom } & 1 & - \\ \text { - } & 26 & 10\end{array}$

$\sum$ Non-conventional

$\sum$ All Primary

Secondary

ah yes
by God
damn it
faith
God
good Christ
icky licky micky
sticky
Jesus
O Lord
O rocks
O well
Singles**

\section{2}

6

4

2

9

3

(1)


Wow wow wow

$\Sigma$ Onomatopoeic

$\Sigma \Sigma$
17

244
1

76

\begin{abstract}
*Joyce's spelling of oh
**ah well, and be damned, a jink a jink a jawbo, and yet and yet, by George, by Jesus, by Jove, Christ, for Jesus' sake, God help us, God of heaven, hohohohohome,

hohohohome, Holy smoke, Holy Wars, Jesusjack, lo and behold, Lord, my God, my word, O dear me, [oh] go away, O God, O hell, O Jesus, O my, O no, O wonder, O yes, rocks, tableau, the bugger, the dickens, well

*** One of these combines with a textual go away and becomes [oh] go away above. Note the reversion to standard spelling because this $o h$ is not in Joyce's text.
\end{abstract}

Table 3

Number of Interjections (I) Spoken in Accord with the Text (T) of Greene's (1984) Screenplay and Added (A) in the Performance of the Film The third man: Primary (Conventional and Non-conventional), Secondary (with German [G] Words Noted), and Onomatopoeic Types

\begin{tabular}{llll}
\hline Types & I & T & A \\
\hline Primary & & \\
\hline
\end{tabular}

Primary

Conventional ah

eh

hallo $(\mathrm{G})$

hello

hey

huh

hum

oh

um

Singles*

6

2

2

4

1

5

1

31

$\begin{array}{ll}3 & \\ - & \end{array}$

$\begin{array}{ll}- & 9\end{array}$

$\sum$ Conventional

17

63

Non-conven- hm

12

tional

$\mathrm{mm}$

18

nu

$-$

1

psst

1

uh

$-$

$-$

6

Singles**

$\begin{array}{ll}- & 6 \\ - & 6\end{array}$

$\sum$ Non-con-

0

ventional 
Secondary for

heaven's

for Pete's

sake

goodness

mein Gott (G)

now

oh dear

oh no

oh please

oh well

oh yes

why

why no

what the

devil

Singles***

$\sum$ Secondary

16

17

Onomatopoeic bang

wht

wha nun

$\sum$ Onomotapoeic

$\underline{\Sigma \Sigma}$

*ach (G), ah ah, ahem, aw, ay, huh huh huh, hum, oho, tsk

**heh, hm hm, uh hm, uh oh, uh vuh hm

***ach so $(\mathrm{G})$, ah ya $(\mathrm{G})$, Mensch $(\mathrm{G})$, na ja $(\mathrm{G})$, no, oh yes yes

${ }^{\wedge} \mathrm{Oh}$ occurs three times only in the footnotes; these are included in this sum.

${ }^{\wedge} \mathrm{O} \mathrm{Oh}$ yes occurs one time only in the footnotes; this is included in this sum.

Substitutions and deletions in these corpora were negligible in frequency of occurrence. Hence, they are not entered in the tables to avoid clutter and are not further considered in our analyses. Omitted from Table 3 are the interjections that occurred in both the novel (40) and the geocities.com transcript (69), since the number of interjections that occurred in the screenplay itself (34) is the proximate textual source of the actors' spoken performances.

Overall, 667 interjections were spoken in the three corpora. The frequency of occurrence and percentages of these are presented in Table 4. Overall and in each of the corpora, primary conventional interjections constitute the greatest number of interjections, and always at least $50 \%$ of all the interjections used. At the other extreme, onomatopoeic interjections are in all instances except Kuralt's Winnie-the-Pooh the least numerous. In the case of Kuralt's Winnie-the-Pooh, the percentage of onomatopoeic interjections is unusually high. This phenomenon does not occur in Dench because the overall number of interjections is highly inflated by her added 
primary interjections; it does not occur in Bennett because most onomatopoeic interjections in the actual text of Winnie-the-Pooh were simply not articulated in the spoken version. The third man contains the highest percentage of primary nonconventional interjections (28\%).

\section{Table 4}

Overall Frequencies (\#) and Percentages (\%) of All Interjections (Both Textual and Added) in the Five Sub-corpora (Kuralt, Dench, and Bennett for Winnie-the-Pooh; Ulysses; and The third man): Primary Conventional, Primary Non-conventional, Secondary, and Onomatopoeic

\begin{tabular}{|c|c|c|c|c|c|c|c|c|c|c|c|c|}
\hline \multirow[b]{3}{*}{ Type } & \multicolumn{6}{|c|}{ Winnie-the-Pooh } & \multicolumn{2}{|c|}{ Ulysses } & \multicolumn{3}{|c|}{ The third man } & $\Sigma$ \\
\hline & \multicolumn{2}{|c|}{ Kuralt } & \multicolumn{2}{|c|}{ Dench } & \multicolumn{2}{|c|}{ Bennett } & \multirow[b]{2}{*}{ \# } & \multirow[b]{2}{*}{$\%$} & \multirow[b]{2}{*}{ \# } & \multirow[b]{2}{*}{$\%$} & \multirow[b]{2}{*}{ \# } & \multirow[b]{2}{*}{$\%$} \\
\hline & $\#$ & $\%$ & $\#$ & $\%$ & \# & $\%$ & & & & & & \\
\hline \multicolumn{13}{|l|}{ Primary } \\
\hline Conventional & 29 & 52 & 48 & 56 & 27 & 60 & 191 & 60 & 80 & 50 & 375 & 56 \\
\hline $\begin{array}{l}\text { Non-con- } \\
\text { ventional }\end{array}$ & 2 & 4 & 17 & 20 & 7 & 16 & 36 & 11 & 44 & 28 & 106 & 16 \\
\hline Secondary & 12 & 21 & 15 & 17 & 8 & 18 & 75 & 23 & 33 & 21 & 143 & 21 \\
\hline Onomatopoeic & 13 & 23 & 6 & 7 & 3 & 7 & 18 & 6 & 3 & 2 & 43 & 67 \\
\hline$\Sigma$ & 56 & 99 & 86 & 100 & 45 & 101 & 320 & 100 & 160 & 101 & 667 & 99 \\
\hline
\end{tabular}

In Table 5, the number of spoken interjections that overlap across the respective corpora is presented. Table 6 presents the percentages of embedded, initial, final, and isolated types of interjections (with respect to ambient pauses) in the respective corpora. It should be noted that, in accord with our previous specifications, Table 6 includes only the first half (159 of 320) of the corpus of spoken interjections from Ulysses (up to p. 479 in the printed version; including CDs 1, 2, and 3 in the spoken version). 
Table 5

Number of Spoken Interjections (I) of the Various Types that Overlap across the Corpora*

\begin{tabular}{|c|c|c|c|c|c|c|}
\hline \multirow[b]{2}{*}{ Type } & \multirow[b]{2}{*}{ I } & \multicolumn{3}{|c|}{ Winnie-the-Pooh } & \multirow[b]{2}{*}{ Ulysses } & \multirow[b]{2}{*}{ The third ma } \\
\hline & & Kuralt & Dench & Bennett & & \\
\hline \multirow{2}{*}{\multicolumn{7}{|c|}{$\begin{array}{l}\text { Primary } \\
\text { Conventional }\end{array}$}} \\
\hline & & & & & & \\
\hline & ah & 3 & 4 & 2 & 26 & 6 \\
\hline & ay & - & - & - & 12 & 1 \\
\hline & $\mathrm{eh}$ & - & 1 & - & 17 & 2 \\
\hline & hallo & 3 & 2 & 3 & - & 3 \\
\hline & huh & - & 1 & 1 & 2 & 5 \\
\hline & oh & 18 & 27 & 14 & 88 & 44 \\
\hline & ow & 3 & 7 & 2 & 1 & - \\
\hline & tsk & - & - & - & 3 & 1 \\
\hline
\end{tabular}

Primary

Non-conven-

tional

$\begin{array}{llllll}\mathrm{hm} & - & 1 & 1 & 1 & 12\end{array}$

Secondary

Christ

1

1

*It should be carefully noted that numbers of interjections in Tables 4 and 5 are not the same, precisely because of the lack of overlap across corpora. Hence, for example, 375 primary conventional interjections are listed in Table 4, whereas only 302 primary conventional interjections are listed in Table 5.

\section{Table 6}

Percentages of All Interjections (Both Textual and Added) at Embedded, Initial, Final, and Isolated Positions Relative to Ambient Pauses for the Respective Corpora: Kuralt, Dench, and Bennett Readings of Winnie-the-Pooh, Readings of Ulysses, and the Film Performance of The third man

\begin{tabular}{lllll}
\hline Position & Winnie-the-Pooh & Ulysses & The third man & $\sum$ \\
& Kuralt Dench Bennett & &
\end{tabular}

$\begin{array}{lrrrrrr}\text { Embedded } & 5 & 8 & 9 & 8 & 30 & 14 \\ \text { Initial } & 50 & 16 & 22 & 54 & 33 & 38 \\ \text { Final } & 10 & 3 & 9 & 13 & 8 & 9 \\ \text { Isolated } & 35 & 73 & 60 & 24 & 29 & 39\end{array}$



hypotheses.

In the following, we relate the data from Tables 1 through 6 to our three

Hypothesis One. In accord with our first hypothesis, Table 6 indicates that only $39 \%$ of the interjections throughout the corpora were temporally isolated by both preceding and following pauses. Once again, the hypothesis of Ameka (1992 b; 1994) that spoken interjections are characteristically isolated by means of a preceding and a following pause must be rejected. Accordingly, the findings of both O'Connell and Kowal (2005 b) and O'Connell et al. (2005) were confirmed. And insofar as 77\% of the interjections across all the corpora were preceded by a pause (i.e., inclusive of both the initial and the isolated types of interjections), the initializing function of interjections was confirmed. In addition to the initializing function thus manifested in a pause before an interjection, there are initializing roles of interjections with respect to certain dialogical verbal units: Utterances themselves (i.e., unified segments articulated sequentially by an individual speaker) constitute such a unit, as do direct reported speech (see Holt 1996) and hypothetical speaker formulation. O'Connell et al. (2005: 161) provide examples from media interviews of Hillary Clinton (HC) in which she uses boy and gee, respectively, at the beginning of the two types of citation:

\section{Direct Reported Speech -- \\ HC: Mario Cuomo said to me boy what did you do to make your husband so mad at you \\ Hypothetical Speaker Formulation -- \\ HC: now you can say from a perspective uh at some distance well gee you know that's a gross generalization}

The difference between the two citation types is simply that boy was actually spoken, whereas gee might have been spoken. Altogether, $75 \%$ of the interjections in these corpora introduced such units: $42 \%$ before utterances and $33 \%$ before direct reported speech. There were very few instances of hypothetical speaker formulation in these corpora, so that less than $1 \%$ of all interjections introduced such units. Accordingly, only $25 \%$ of all interjections occurred within utterances.

Hypothesis Two. As Table 5 indicates, overall 191 of the 375 primary conventional interjections $(51 \%)$ are $o h$, and $41(11 \%)$ are $a h ; o h$ and $a h$ are also the only interjections of any type that occur in all five sub-corpora. The fact that they are both primary conventional interjections clearly supports the first part of our second hypothesis: that overlap in the occurrence of specific interjections across corpora would be limited dominantly to primary conventional interjections. The interjections $\mathrm{eh}, \mathrm{hm}$, ay, ow, and hallo were next in frequency $(20,15,13,13$, and 11, respectively), but ay was common only across two corpora, The third man and Ulysses. All but one $(\mathrm{hm})$ of these were also primary conventional interjections; hence, $h m$ was the only primary non-conventional interjection that was present across all three corpora.

A complementary analysis comparing all the literary readings to the artistic performance with respect to the occurrence of primary conventional, primary non- 
conventional, secondary, and onomatopoeic types of interjections yielded a significant inferential statistic. The percentages of the respective types in the literary readings were $58 \%, 12 \%, 22 \%$, and $8 \%$; the corresponding percentages for the artistic performance were $50 \%, 28 \%, 21 \%$, and $2 \%$ (see Table 4 ). Hence, in keeping with a conventional chi square nonparametric inferential statistical formula with three degrees of freedom, $X^{2}$ $(3)=10.52, p<.02$. In other words, the primary conventional interjections were significantly less frequent and the primary non-conventional significantly more frequent in the artistic performance than in the literary readings at a probability level of less than .02 .

The occurrence of primary non-conventional interjections in the printed text of the corpora was negligible (29 in Winnie-the-Pooh and Ulysses, none in either the novel or screenplay of The third man), confirming the second part of hypothesis two: that primary non-conventional interjections would seldom occur in textual versions of the corpora. Their lack of morphological well-formedness is indeed characteristic of conceptual orality rather than conceptual literacy.

Hypothesis Three. Tables 1, 2, and 3 show that there were indeed added interjections in all the corpora relative to the interjections in the text. Overall, 39\% (259/667) of all interjections were added. The Winnie-the-Pooh (Table 1) and Ulysses (Table 2) additions combined to only 26\% (133/507) of all the interjections spoken in those corpora. By contrast, The third man (Table 3) additions combined to fully $79 \%$ $(126 / 160)$ of the interjections spoken in the film. Hence, our hypothesis that the literary readings and the artistic performance would be widely divergent in this respect has been supported. Fully $60 \%(156 / 259)$ of all the added interjections were primary conventional; 30\% (77/259) were primary non-conventional; 7\% (19/259) were secondary; and 3\% (7/259) were onomatopoeic. In other words, most of the added interjections $(90 \%)$ were primary interjections.

\section{Discussion}

Our main findings on numerosity and privileges of occurrence of the various types of interjections provide evidence for our contention that literary readings and artistic performance are indeed different genres. Whereas the readers changed their text only moderately by adding $26 \%$ of all spoken interjections, the actors in their artistic performance added $79 \%$ of all spoken interjections.

With respect to the temporal integration of interjections, a consistent difference was also found between the two genres. In fact, this difference becomes even more pronounced if one adds to the present data those of the interviewee Hillary Clinton from the O'Connell et al. (2005) research. One might argue that the interviewee's speech is the most spontaneous and the most characterized by conceptual orality, since her dependence on a text is less than in the artistic performance and in turn even less than in the literary readings. The percentages of embedded positions of interjections from literary readings through artistic performance to interviewee's speech are $8 \%<30 \%<$ $54 \%$. Initial $(40 \%>33 \%>31 \%)$ and isolated $(42 \%>29 \%>12 \%)$ positions diminish inversely, and, when combined, diminish quite notably: $82 \%>62 \%>43 \%$. The extremely high initialization role of interjections in the literary readings corresponds closely with the well-formedness of the printed text; the intermediate initialization of 
The third man reflects a loose dependence on the screenplay and on the general plot development; the relatively low percentage of initialization in the speech of the interviewee reflects a notable freedom of the speaker from any literate constraints of a printed text. In turn, the high percentage of embedding in this instance suggests an authentic personal connection of the emotionality expressed in such interjections with the following cognitive content of the speaker; again, it seems to reflect personal authorship of both the emotional and cognitive components.

To return to the data of the present research, in an artistic performance, the actors do not read, but rather commit material to memory as the fundamental gist of what they are to bring to life through word, gesture, and enactment in interplay with other actors. Actors go far beyond the role of "animators" and assume instead the role of "principals" (Goffman 1981: 226). In doing so, they become the dramatis personae, sharing in some measure the very role of authorship of the piece. Literary readers remain for the most part the animators of someone else's writings - essentially via words enriched with appropriate prosody.

The supplementary authorship brought by the actors to The third man was not at all a sort of cognitive textual contribution, but a live emotional addition that often served an initializing function as well. Thus, the added interjections join with laughter, fillers, hesitations, gestures, and a host of other prosodic and paralinguistic means by which a literate text in well-formed, punctuated, grammatical structure is transformed from literacy into the domain of orality. It is no accident that the frequency of interjections in the novel (40) and the screenplay (34) of The third man is quite minimal, and that not a single primary non-conventional interjection occurs in either the novel or the screenplay. On the other hand, the fact that only 69 interjections occur in the geocities.com transcript of the film indicates simply that the literate bias of transcribers renders interjections inappropriate or at least negligible in their transcriptions; more than half $(91 / 160=57 \%)$ of the interjections that were actually spoken in the film were disregarded in the geocities.com transcript. Only in our detailed transcript of the film itself does the conceptual orality of the actors' artistic performance emerge, as reflected in the rich abundance of interjections (see Table 3).

Only one primary non-conventional interjection $(\mathrm{hm})$ was common across all three corpora (see Table 5). It has been categorized as a primary non-conventional interjection because it does not appear in Merriam-Webster's collegiate dictionary (2003). However, insofar as it is listed as both an English and a German primary conventional interjection in Langenscheidts Enzyklopädisches Wörterbuch der englischen und deutschen Sprache (1996), there is reason to consider hm conventional.

Another reflection of the emotional function of interjections can be found in the secondary interjections. In the children's diction of Winnie-the-Pooh there are no secondary interjections at all that refer in any way to the deity or to transcendent phenomena (see Table 1). However, in Ulysses and The third man, 67\% (50/75) and $15 \%(5 / 33)$, respectively, of the spoken secondary interjections make reference to either the deity or some other transcendent phenomenon (e.g., hell; see Tables 2 and 3). An unusual characteristic of these interjections is that none of these five secondary interjections occur in the novel The third man, whereas all 50 of the secondary interjections spoken by the readers of Ulysses are in the printed text. This provides one more indication that the literary readers are animators rather than principals or in any sense authors, whereas the actors in the artistic performance bring an additional richness 
to what is given in the printed version by adding primary and secondary (and even a few onomatopoeic) interjections.

The frequency of occurrence of $o h$ and $a h$ in Table 5 (and to a lesser extent, of other one-syllable primary conventional interjections such as $e h, a y$, and $o w$ ) reflects the emotional quality expressed by these strong vowels. This function is traceable in the English language back as far as the fifteenth century and beyond (see Oxford English Dictionary 1954). Interestingly enough, our findings regarding oh confirm Aijmer's (1987: 61) observation for spontaneous conversations in the London-Lund corpus that $o h$ was "among the most frequent words in the corpus." By contrast, the fillers $u h$ and um reflect the phonetic weakness of the schwa and seem incapable of expressing strong emotion (see O'Connell \& Kowal 2005 b; O'Connell et al. 2005).

We concluded a recent article on laughter in The third man (O'Connell \& Kowal 2006) with the generalization: "An enactment of life comes to life on screen or stage as medial and conceptual orality, with all the prosodic, paralinguistic, and verbal devices necessary to lure an audience into the dramatic convention." One of those devices is the use of interjections, and not least of all a use of interjections added by the actors themselves as principals or dramatis personae who share through their creative performance in the authorship of the piece, in this case The third man - a use quite different from the characteristic use of interjections by the animators in literary readings.

Are we now any closer to discovering what interjections mean? Perhaps some playful hyperbole elicited from Rabbit by Pooh himself can throw some light on the question (Milne 1926: 93):

"We say 'Aha!' so that Kanga knows that we know where Baby Roo is. 'Aha' means 'We'll tell you where Baby Roo is, if you promise to go away from the Forest and never come back.' Now don't talk while I think."

Obviously, that's too large an order for a simple, two-syllable, primary conventional interjection to fulfill. But perhaps the important thing to note is that interjections do change the meaning of otherwise much more meaningful words in discourse. Along with fillers, hesitations, laughter, gestures, and a wealth of prosodic and paralinguistic variations, interjections add to discourse a richness and subtlety that the otherwise very important content words are incapable of imparting to a listener. And in doing so, interjections bring us closer to the very essence of spontaneous spoken discourse. What interjections carry to the listener are an emotional stance and a perspective on the part of the speaker or, in the present instance, the actor. Whereas the literary readers are typically seated before a microphone to read a script, the actors in an artistic performance move about on stage and speak freely. Their level of engagement in the emotional impact of the moment is thus seen to be quite a bit greater than that of the literary reader.

To sum up, literary readings, artistic performance, a penguin's ugh, and a Rabbit's aha may all throw light on the functions of interjections. The Wundtian cries of an infant move ineluctably from high-pitched pain reports to a sophisticated ow or ouch to the hardly writable wild interjections of the school yard and playing field to the complicated and sophisticated artistic usage reviewed and analyzed herein. We have a great deal more to learn about interjections. 


\section{References}

Aijmer, K. (1987) Oh and ah in English conversation. In W. Meijs (ed.), Corpus linguistics and beyond: Proceedings of the Seventh International Conference on English Language Research on Computerized Corpora, Vol. 59. Amsterdam: Costerus, pp. 61-86.

Ameka, F. (ed.) (1992 a) Interjections. Journal of Pragmatics Special Issue 18: ix-301.

Ameka, F. (1992 b) Interjections: The universal yet neglected part of speech. Journal of Pragmatics 18: 101-108.

Ameka, F. (1994) Interjections. In R.E. Asher (ed.), The encyclopedia of language and linguistics Vol. 2. Oxford: Pergamon Press, pp. 1712-1715.

Angermeyer, A. (1979) Die Interjektion. Linguistik und Didaktik 10: 39-50.

Bennett, A., R. Briers, and F. Kendal (speakers) (1988) Winnie-the-Pooh (cassette recording). New York: Bantam Doubleday Dell Audio Publishing.

Burger, H. (1980) Interjektionen. In H. Sitta (ed.), Ansätze zu einer pragmatischen Sprachgeschichte: Zürcher Kolloquium 1978. Tübingen: Niemeyer, pp. 53-69.

Burkhardt, A. (1998) Interjektionen: Begriff, Geschichte(n), Paraphrasen. In T. Harden and E. Hentschel (eds.), Particulae particularum. Festschrift für Harald Weydt. Tübingen: Niemeyer, pp. 43-73.

Clark, H.H., and J.E. Fox Tree (2002) Using uh and um in spontaneous speaking. Cognition 84: 73-111.

Eastman, C.M. (1992) Swahili interjections: Blurring language-use/gesture use boundaries. Journal of Pragmatics 18: 273-287.

Ehlich, K. (1986) Interjektionen. Tübingen: Niemeyer.

Fries, N. (1988) Interjektionen und Interjektionsphrasen. Sprache und Pragmatik 17: 1-43.

Fries, N. (1990) Zur Grammatik von Interjektionen. In E. Feldbusch, R. Pogarell, and C. Weiß (eds.), Neue Fragen der Linguistik. Akten des 25. Linguistischen Kolloquiums, Paderborn 1990. Band 1: Bestand und Entwicklung. Tübingen: Niemeyer, pp. 283-295.

Fries, N. (1992) Interjektionen, Interjektionsphrasen und Satzmodus. In I. Rosengren (ed.), Satz und Illokution 1. Tübingen: Niemeyer, pp. 307-341.

Goffman, E. (1981) Forms of talk. Philadelphia: University of Pennsylvania Press.

Greene, G. (1950) The third man [novel]. Hammondsworth, Middlesex, England: Penguin Press.

Greene, G. (1984) The third man (rev. ed.) [screenplay]. London: Lorrimer.

Hansen, M.-B.M. (1998) The function of discourse particles. A study with special reference to spoken standard French. Amsterdam: John Benjamins.

Harris, R. (1980) The language-makers. London: Duckworth.

Holt, E. (1996) Reporting on talk: The use of direct reported speech in conversation. Research on Language and Social Interaction 29: 219-245. 
Jacquet, L. (director) (2005) March of the penguins. Warner Bros. Entertainment Inc.

Jespersen, O. (1922) Language: Its nature, development, and origin. London: George Allen \& Unwin.

Joyce, J. (1960) Ulysses. London: The Bodley Head.

Jucker, A.H., and S.W. Smith (1998) And people you know like 'wow': Discourse markers as negotiating strategies. In A.H. Jucker and Y. Ziv (eds.), Discourse markers: Descriptions and theory. Amsterdam: Benjamins, pp. 171-201.

Karcevski, S. (1941) Introduction à l'étude de l'interjection. Cahiers F. de Saussure 1: 57-75.

Kleeman, F. (1980) Der Gebrauch der Interjektionen bei Wilhelm Busch. Sprachpflege 20: 8-11.

Koch, P, and W. Oesterreicher (1994) Schriftlichkeit und Sprache. In H. Günther and O. Ludwig (eds.), Schrift und Schriftlichkeit. Writing and its use. Ein interdisziplinäres Handbuch internationaler Forschung. An interdisciplinary handbook of international research. Berlin: de Gruyter, pp. 587-604.

Korda, A., D.O. Selznik (producers), and C. Reed (director) (1949) The third man [motion picture]. (Available from Home Vision Cinema, 4411 Ravenswood Avenue, Chicago, IL 60640-5802)

Kowal, S., and D.C. O’Connell (2004) Interjektionen im Gespräch. Zeitschrift für Semiotik 26: 85-99.

Kuralt, C. (speaker) (1998) The Winnie-the-Pooh read-aloud collection vol. 1. [cassette recording]. New York: Dutton Children's Books.

Langenscheidts Enzyklopädisches Wörterbuch der englischen und deutschen Sprache: "Der Grosse Muret-Sanders." $11^{\text {th }}$ ed. 2 vols. (1996) Berlin: Langenscheidt.

Merriam-Webster's collegiate dictionary. $11^{\text {th }}$ ed. (2003) Springfield, MA: Merriam-Webster.

Milne, A.A. (1926) Winnie-the-Pooh. New York: Dutton Children's Books.

Milne, A.A., S. Fry, J. Dench, J. Horrocks, G. Palmer, and M. Williams (1998) Pooh goes visiting: And other stories [cassette recording]. England: Hodder Headline Audiobooks.

Müller, C., and R. Posner (eds.) (2004) The semantics and pragmatics of everyday gestures. Berlin: Weidler.

Norton, J., and M. Riordan (speakers) (1994) Ulysses. Germany: Naxos AudioBooks.

Nübling, D. (2004) Die prototypische Interjektion: Ein Definitionsvorschlag. Zeitschrift für Semiotik 26: $11-45$.

O'Connell, D.C., and S. Kowal (2004) The history of research on the filled pause as evidence of The written language bias in linguistics (Linell 1982). Journal of Psycholinguistic Research 33: 459-474.

O'Connell, D.C., and S. Kowal (2005 a) Uh and Um revisited: Are they interjections for signaling delay? Journal of Psycholinguistic Research 34: 555-576.

O'Connell, D.C., and S. Kowal (2005 b) Where do interjections come from? A psycholinguistic analysis of Shaw's Pygmalion. Journal of Psycholinguistic Research 34: 497-514.

O’Connell, D.C., and S. Kowal (2006) Laughter in The third man. Pragmatics 16: 2/3.

O'Connell, D.C., S. Kowal, and C. Ageneau (2005) Interjections in interviews. Journal of Psycholinguistic Research 34: 153-171. 
O’Connell, D.C., S. Kowal, and E.J. Dill III (2004) Dialogicality in TV news interviews. Journal of Pragmatics 36: 185-205.

Oxford English Dictionary (1954) Oxford: Oxford University Press.

Pascal, G. (Producer), A. Asquith, and L. Howard (Directors) (1938) Pygmalion [Motion picture]. (Available as VHS or DVD from http://www.amazon.com)

Pompino-Marschall, B. (2004) Zwischen Tierlaut und sprachlicher Artikulation: Zur Phonetik der Interjektion. Zeitschrift für Semiotik 26: 71-84.

Reisigl, M. (1999) Sekundäre Interjektionen: Eine diskursanalytische Annäherung. Frankfurt/Main: Peter Lang.

Rhodes, R.A. (1992) Interjections. In W. Bright (ed.), International encyclopedia of linguistics Vol. 1. New York: Oxford University Press, p. 222.

Schneider, W. (1959) Stilistische deutsche Grammatik. Basel: Herder.

Shaw, G.B. (1916/1969) Pygmalion: A romance in five acts and my fair lady: A musical play in two acts. New York: Signet.

Svartvik, J., and R. Quirk (1980) (eds.) A corpus of English conversation. Lund: Gleerup.

Tesnière, L. (1936) Sur la classification des interjections. In A. Sestak \& A. Dokoupil (eds.), Mélanges dédiés à la mémoire de Prokop M. Haškovec par ses amis et élèves. Brno: Globus, pp. 343-410.

Wilkins, D.P. (1992) Interjections as deictics. Journal of Pragmatics 17: 119-158.

Wundt, W. (1900) Völkerpsychologie. Erstes Buch: Die Sprache. Leipzig: Engelmann.

Yang, E. (2004) Interjektionen im Sprachvergleich: Deutsch versus Chinesisch. Zeitschrift für Semiotik 26: 47-69. 